\title{
Pola Asuh Orang Tua di Desa Nggele terhadap Pembentukan Karakter Anak
}

\author{
Ira rauf ${ }^{1}$, Pairin $^{2}$, Faizah Binti Awad ${ }^{3}$ \\ ${ }^{1}$ Institut Agama Islam Negeri Kendari \\ ${ }^{2}$ Institut Agama Islam Negeri Kendari, Indonesia. E-mail: pairinma@yahoo.co.id \\ ${ }^{3}$ Institut Agama Islam Negeri Kendari, Indonesia. E-mail: izzahawad@gmail.com
}

\begin{tabular}{|c|c|}
\hline Articel info & Abstract \\
\hline $\begin{array}{l}\text { Artikel history: } \\
\text { Received: } 4 \text { April } 2020 \\
\text { Revised: } 18 \text { April } 2019 \\
\text { Accepted: } 18 \text { April } 2020\end{array}$ & $\begin{array}{l}\text { The objective of this study is to investigate parenting style towards student's } \\
\text { character building, understand the character showed with particular } \\
\text { parenting style, and to determine some factors which may determine the } \\
\text { parenting style in the building of student's character. This research is a } \\
\text { descriptive qualitative study with case study approach. The source of the } \\
\text { data was parents and their children as the primary data, and other related } \\
\text { persons as the secondary data. The data were collected by observation, } \\
\text { documentation, and interview then were analyzed through data reduction, } \\
\text { data presentation, and triangulation. The study showed that Democratic } \\
\text { parenting, Laissez faire, Authoritarian, and situational were the way of the } \\
\text { parents in educating their children; student's character showed with those } \\
\text { parenting styles were that children become independent, children depend on } \\
\text { parents, children become stubborn, and children become obedient to } \\
\text { parents. Factors influencing parental care were background patterns of } \\
\text { parenting that previously obtained, economic status and work of parents, } \\
\text { level of education of parents, physical social environment where the family } \\
\text { lives. }\end{array}$ \\
\hline
\end{tabular}

Keywords: Parenting Style, Children's Character

\begin{tabular}{|c|c|}
\hline Informasi Artikel & Abstrak \\
\hline $\begin{array}{l}\text { Riwayat Artikel: } \\
\text { Diterima: } 4 \text { April } 2020 \\
\text { Direvisi: } 18 \text { April } 2020 \\
\text { Accepted: } 18 \text { April } 2020\end{array}$ & $\begin{array}{l}\text { Tujuan penelitian ini: untuk mengetahui dan mendeskripsikan tentang } \\
\text { bagaimana pola asuh orang tua terhadap pembentukan karakter anak; untuk } \\
\text { mengetahui karakter yang nampak pada anak dari pola pengasuhan yang } \\
\text { didapatkan; untuk mengetahui dan mendeskripsikan faktor yang } \\
\text { mempengaruhi pola asuh orang tua terhadap pembentukan karakter anak. } \\
\text { Penelitian ini menggunakan pendekatan deskriptif kualitatif dengan jenis } \\
\text { penelitian studi kasus, yang terdiri dari lima bab, dengan menggunakan dua } \\
\text { sumber penelitian yaitu sumber data primer dan sekunder. Informan utama } \\
\text { yaitu orang tua dan anak, informan pendukung yaitu orang yang mengetahui } \\
\text { problema mengenai objek yang diteliti. Untuk memperoleh data yang akurat, } \\
\text { peneliti menggunakan teknik pengumpulan data yang berupa Wawancara, } \\
\text { Observasi, dan Dokumentasi dengan teknik analisis data yakni: } \\
\text { pengumpulan data, reduksi data, penyajian data. Untuk pengecekan } \\
\text { keabsahan data diuji melalui pendekatan triangulasi sumber dan data. } \\
\text { Penelitian ini ditemukan hasil bahwa: Pola asuh orang tua menggunakan }\end{array}$ \\
\hline
\end{tabular}


pola asuh Demokratis, Laissez faire, Otoriter, dan situasional. Karakter anak yang nampak yakni; Anak menjadi mandiri, anak bergantung kepada orang tua, anak menjadi bandel, anak menjadi penurut kepada orang tua. Faktor yang mempengaruhi pola asuh orang tua; Latar belakang pola pengasuhan yang didapatkan sebelumnya, status ekonomi serta pekerjaan orang tua, tingkat pendidikan dari orang tua, lingkungan sosial fisik tempat dimana keluarga itu tinggal.

DOI:

Kata Kunci: Pola Asuh Orang Tua, Karatakter Anak

\section{PENDAHULUAN}

Pola asuh merupakan faktor penetu dalam proses pembentukan karakter anak. Pola asuh anak diawali dalam lingkungan keluarga yakni dengan adanya interaksi antara anak dengan orang tua maupun dengan keluarga lainnya yang dilakukan secara berulang-ulang sehingga menjadi kebiasaan yang kemudian membentuk watak, akhlak, tabiat atau kepribadian yang disebut sebagai karakteristik diri (Akmal, 2017). Pendidikan anak berawal dari lingkungan keluarga karena lingungan keluarga adalah hal pertama yang anak kenali sebelum dunia luarnya seperti lingkungan sekolah dan lingkungan masyarakat. Jadi, orang tua atau keluarga bisa dikatakan sebagai benih pembentukan pertama dari kepribadian atau karakter anak. Soemarjan, Abdullah, \& Jailan, 2014) mengatakan bahwa pendidikan awal anak dimulai dalam lingkungan keluarga. Dalam proses pembentukan karakter terdapat tiga faktor penting yang mendukung pembentukan karakter tersebut yakni faktor pendidikan (sekolah), lingkungan keluarga, dan lingkungan masyarakat subianto \& Koesoema (2013). Dalam lingkungan keluarga, orang tualah yang memiliki peran yang sangat penting dalam proses pembentukan karakter anak. Sebab disadari ataupun tidak disadari anak akan mencontoh orang tua dengan meniru prilaku, tata acara pergaulan, dan aktivitas sehari-harinya. Selain orang tua, keluarga lainnya yang ikut serta dalam mengasuh anak seperti kakek dan nenek juga memiliki tanggung jawab yang sama dalam memberikan sumbangsi bagi kebutuhan perkembangan anak. Sebagaimana dalam (dkk, 2016) bahwa kepribadian orang tua, cara hidup dan unsur-unsur pendidikan yang secara tidak langsung akan masuk kedalam pribadi anak yang tumbuh.

Pengasuhan anak sejak usia dini adalah bagian penting dan mendasar dalam menyiapkan anak untuk menjadi masyarakat yang baik. Sebab, anak merupakan generasi penerus bangsa. (Solehuddin, 2013) Untuk itu perlunya pemberian pola asuh yang baik sejak usia dini dianggap sangat penting dan fundamental. Karena usia tersebut merupakan titik penentu bagi pembentukan karakter seseorang. Namun terkadang banyak orang tua yang tidak menyadari bahwa pembentukan dasar-dasar pendidikan adalah dalam lingkungan keluarga. Mereka menganggap bahwa tanggung jawab tersebut akan lebih baik bila diserahkan sepenuhnya kepada guru di sekolah, dan yang menjadi tanggung jawabnya hanyalah mencari nafkah sekuat tenaga untuk membiayai pendidikan anak-anaknya. Berdasarkan hasil observasi peneliti di SD Inpres 2 Nggele, peneliti menemukan bahwa beberapa siswa yang bersekolah di SD Inpres 2 Nggele memiliki gejala prilaku yang kurang baik, atau tidak sesuai dengan tata tertib sekolah. Mengingat perubahan prilaku ini sangat berperan penting bagi masa depan anak, maka perlu adanya usaha bersama dari guru dan orang tua siswa dalam mendidik prilaku siswa dengan lebih intens lagi. Sebab perilaku yang menjadi kebiasaan siswa di lingkungan formal maupun lingkungan nonformal siswa akan berdampak pada pembentukan watak atau karakter anak kelak.

\section{METODE}

Jenis penelitian ini merupakan jenis penelitian deskriptif kualitatif yaitu penelitian yang menggambarkan sekaligus mengkaji kondisi nyata tentang "Pola Asuh Orang Tua di Desa Nggele Terhadap Pembentukan Karakter Anak (Studi kasus: terhadap siswa/siswi Sekolah Dasar Inpres 2 Nggele)". Yang ditelaah, ditafsirkan, yang kemudian dikembangkan, dan disajikan dalam bentuk deskriptif kualitatif. Adapun pendekatan dalam penelitian ini, yaitu pendekatan studi kasus. Yang dimana penelitian studi kasus merupakan penelitian dengan menggunakan penyelidikan mendalam (indept-study) mengenai suatu unit sosial sedemikian rupa sehingga menghasilkan gambaran yang terorganisasikan dengan baik dan lengkap mengenai unit sosial tersebut. (Karsdi, 2018) Untuk itu peneliti menggunakan pendekatan ini untuk menjawab permasalahan dalam fokus penelitian dan rumusan masalah yang penulis jadikan sebagai acuan. 
Penelitian ini dilaksanakan di Desa Nggele Kecamatan Taliabu Barat Laut Kabupaten Pulau Taliabu selama 4 bulan yakni dari bulan Juni sampai bulan September, terhitung setelah proposal penelitian selesai diseminarkan sampai penelitian ini dirangkum menjadi skripsi. Dalam penelitian ini peneliti menggunakan dua jenis sumber data yakni sumber data primer dan sumber data sekunder. Sumber data primer dalam penelitian ini dikhususkan pada masyarakat Desa Nggele yang anaknya bersekolah di SD Inpres 2 Nggele. Yaitu orang tua dari siswa yang berjumlah 26 orang, anak yang bersekolah di Sekolah Dasar Inpres 2 Nggele yang berjumlah 11 orang serta kakek/nenek anak sebanyak 4 orang. Sumber data sekunder yaitu data yang melalui dokumen kantor Desa Nggele dan referensi perpustakaan yang relevan dengan judul penelitian. Untuk memperoleh kevalidan data tentang masalah yang akan diteliti maka peneliti menggunakan beberapa teknik dalam pengumpulan data yaitu: Teknik Wawancara, Observasi, serta Dokumentasi. Teknik Analisis Data dan Pengolahan Data, Dalam penganalisisan dan pengolahan data peneliti menggunakan teknik dari (Milles, Huberman, \& Karsadi, 2018), yang terdiri dari tiga bagian yakni; Mengumpulkan data, mereduksi data data display (Penyajian Data). Untuk pengecekan keabsahan data dalam penelitian ini, peneliti menggunakan teknik triangulasi. Pada penelitian ini, peneliti menggunakan 2 jenis triangulasi yakni; Triangulasi sumber dan triangulasi data.

\section{HASIL PENELITIAN}

\section{Pola Asuh Orang Tua di Desa Nggele Terhadap Pembentukan Karakter Anak}

Berdasarkan hasil wawancara dan pengamatan peneliti dengan beberapa informan yakni para orang tua di Desa Nggele, peneliti menemukan beberapa pola asuh yang diterapkan para orang tua yang berada di Desa Nggele yakni; Membiasakan anak untuk selalu mandiri. Karena keterbatasan waktu, orang tua membiasakan anak-anaknya untuk hidup secara mandiri dan memberikan kebebasan kepada anak untuk bertindak tanpa meminta tanggapan orang tua. Hal ini dilakukan agar anak dapat mengurus diri sendiri ketika para orang tua sedang keluar untuk bekerja. Selain itu, para orang tua juga mengajarkan anak pemahaman tentang agama, seperti mengaji, sholat dan lain sebagainya. Bukan hanya itu, orang tua di sana juga mendidik anak agar berkarakter yang baik yakni dengan mengajarkan bagaimana cara kita bertutur sapa, cara kita berprilaku dan lain sebagainya, meskipun dalam pelaksanaannya terkadang masih ada anak yang tidak menerapkan apa yang diajarkan oleh orang tuanya dalam kehidupan sehari-hari. Untuk itu salah satu cara yang mampu dilakukan orang tua dalam membentuk karakter yang baik bagi anak adalah dengan menjadi modelling (contoh teladan yang baik bagi anak), sebagai mentorring (mentor) yang bisa memberikan kasih sayang dan perlindungan, sebagai teacher (guru) yang memilki tugas untuk mengajari anak tentang nilai-nilai moral, dan sebagai organizing (mengatur, mengontrol anak dan bekerja sama dalam menyelesaikan permasalahan anak). (Covey \& Istiani, 2013). Dan pola asuh yang diterapkan juga ada yang dengan cara memberikan perhatian penuh dalam pengasuhan dan memperhatikan masa depan anak. seperti mulai dari mendukung kegiatan sekolah dan perencanaan masa depan anak sangat diperhatikan. Kemudian ada juga yang mengasuh dengan cara memberikan kebebasan kepada anak dalam melakukan hoby dan kemauannya.

Orang tua siswa memang mendukung aktivitas anak-anaknya dengan cara memberi kebebasan kepada siswa untuk menentukan dan menekuni hoby-nya. Namun tetap tidak lepas dari pengawasan orang tua. Para orang tua masih sering memberi arahan kepada anak bahwa anak boleh menekuni hobinya, asalkan hoby itu tidak mengganggu kegiatan mereka yang lain seperti belajar. Selain itu para orang tua juga melakukan kontrol terhadap penggunaan media dan aktivitas anak. Dalam (Rahmad, Islami Alternatif Ceramah-Ceramah Dikampus, 2018) mendidik diperlukan adanya pengawasan terhadap aktivitas anak, dan salah satu cara yang mampu dilakukan orang tua untuk mengawasi aktivitas anak adalah dengan cara mengontrol atau membatasi penggunaan medianya. Hal ini berguna untuk membantu anak agar tidak terlalu ketagihan dalam bermain. Apalagi di zaman sekarang, ratarata anak yang masih dibangku sekolah dasar sudah memiliki "gadget" bahkan ada diantaranya yang membawa serta gadget-nya ke sekolah. Para orang tua di Desa Nggele sudah berusaha untuk mengawasi aktivitas anak-anaknya yakni dengan membatasi penggunaan handphone pada anak dan membatasi aktivitas yang berhubungan dengan media. Namun, sebagian orang tua masih ada yang belum mengerti dengan penggunaan handphone dan internet maka terkadang para orang tua tidak bisa mengecek aktivitas media yang dilakukan oleh anaknya secara langsung. 


\section{Model Karakter Yang Nampak pada anak Dari Adanya Pola Pengasuhan Yang dilakukan orang tua}

Anak menjadi mandiri. Pola asuh yang diterapkan oleh orang tua di Desa Nggele dapat terlihat bahwa anak sudah mulai mandiri akibat dari pola pengasuhan yang mereka dapatkan. Seperti yang peneliti temukan dari hasil wawancara dan pengamatan peneliti bahwa anak di Desa Nggele yang bersekolah di SD Inpres 2 Nggele sudah mulai bisa mencari uang sendiri untuk mencukupi sedikit kebutuhannya. Yakni dengan membantu orang lain dalam berjualan ataupun membantu dengan tenaga. Sifat kemandirian juga dapat dilihat dari keseharian anak yang sudah mulai mandiri dalam mengurus keperluannya sendiri, seperti sudah bisa membersihkan pakaiannya sendiri dan bahkan sudah mampu membantu mencucikan baju orang tua serta adiknya. Karakter berikutnya yang timbul yakni anak menjadi penurut dan mendengarkan arahan orang tua. Sikap atau perilaku ini ditunjukan oleh anak yang ketika diarahkan oleh ibunya dia mendengar dan mengikuti apa yang ibunya sampaikan. Sebagaimana yang peneliti lihat bahwa anak ini menurut ketika anak disuruh ibunya untuk bermain di sekitar rumah dan si anak mengikuti arahan dari orang tuanya.

Anak menjadi bergantung kepada orang tua. Karena pola pengasuhan yang diberikan oleh orang tua di Desa Nggele terlalu bersifat memanjakan anak, akibatnya membuat anak tidak terlatih secara intens untuk melakukan kegiatannya sendiri. sehingga anak menjadi manja dan tidak bisa melakukan aktivitasnya jika tidak didampingi oleh orang tuanya. Sifat berikutnya anak menjadi bandel. Berdasarkan hasil pengamatan peneliti, Peneliti menemukan fakta bahwa ada anak di Desa Nggele yang sering berkeliaran di kampung ketika pulang sekolah, tidak perduli panas atau hujan. Ketika dipanggil pulang oleh ibunya kadang dia hanya pulang sebentar kemudian pergi lagi lewat pintu belakang tanpa sepengetahuan orang tuanya. Hingga orang tua anak juga kadang merasa kewalahan dalam menanggulangi perilaku anaknya. Untuk itu orang tuanya lebih memilih untuk membiarkan apapun yang dilakukan anak.

Faktor yang mempengaruhi pola asuh orang tua di Desa Nggele

Faktor yang bisa mempengaruhi pola asuh orang tua (Agustiawati, 2014) yaitu; Latar belakang pola pengasuhan yang didapatkan sebelumnya. Apabila para orang tua di Desa Nggele menganggap bahwa pola asuh yang mereka dapatkan sebelumnya sangat baik maka mereka tidak segan untuk menerapkan secara langsung pola asuh tersebut kedalam keluarganya pula yakni kepada anak-anaknya. Namun terkadang ada juga orang tua yang tidak mau terlalu memaksa anaknya untuk seperti dirinya. Hal ini dikarenakan oleh pola asuh yang dia dapatkan sebelumnya dianggap cukup berat. Sehingga dia tidak ingin hal tersebut terjadi pula dalam kehidupan anaknya. Faktor berikutnya, status ekonomi serta pekerjaan orang tua. Orang tua yang cenderung sibuk dalam urusan pekerjaan terkadang jadi kurang memperhatikan keadaan anak-anaknya. Di Desa Nggele ada pula orang tua yang pola pengasuhannya dipengaruhi oleh faktor ekonomi serta pekerjaan orang tua, yaitu dengan keterbatasan ekonomi membuat para orang tua terhambat dalam memenuhi kebutuhan anak-anaknya. Oleh karena itu para orang tua mencoba untuk bekerja lembur seharian agar pendapatan yang mereka dapatkan bisa mencukupi kebutuhan mereka. Apabila mereka mendapatkan penghasilan lebih mereka maka mereka akan menabung untuk biaya pendidikan anaknya kelak. Sehingga dengan keterbatasan waktu luang yang mereka punya menyebabkan kurangnya komunikasi antara orang tua dan anak.

Tingkat pendidikan orang tua. Orang tua yang memiliki pemahan yang berbeda tentunya akan berbeda juga cara pengasuhan yang diberikan kepada anak. Orang tua di Desa Nggele ada yang mendidik anaknya dengan mencari cara agar supaya bagaimana anaknya tidak bermain sembarangan di luar rumah, yakni membelikan mainan yang bisa membuat anaknya betah bermain di rumah saja. Dan dalam memberi arahan kepada anak selalu dengan bahasa yang halus dan tidak kasar sehingga membuat anak luluh akan arahan orang tua. Dan ada pula yang mengambil solusi lebih kepada memberikan kebebasan kepada anaknya untuk melakukan kemauannya sampai anaknya merasa puas dengan apa yang akan dia lakukan. Berikutnya, lingkungan sosial fisik tempat dimana keluarga itu tinggal. Hasil wawancara dan pengamatan peneliti, terlihat bahwa pola asuh orang tua sangat dipengaruhi pula oleh faktor lingkungan sosial dan fisik tempat dimana keluarga itu tinggal. Seperti yang diungkapkan oleh pak Ampera bahwa dia merasa malu bila anak-anaknya tidak mendapatkan pendidikan seperti anak-anak yang lain, dikarenakan dalam lingkungan tempat tinggalnya rata-rata anak-anak itu sudah menempuh pendidikan sampai ke perguruan tinggi. Jadi iapun berusaha sekuat tenaga untuk bekerja agar bisa membiayai sekolah anaknya nanti. Serta ada juga orang tua yang sering 
memberikan contoh kepada anak-anaknya dengan menyuruh anaknya untuk melncotohi sikap atau perilaku baik dari anak tetangganya.

\section{PEMBAHASAN}

Dari hasil paparan di atas, maka secara umum terdapat beberapa pola asuh yang diterapkan oleh orang tua di Desa Nggele terhadap pembentukan karakter anak/siswa yang bersekolah di SD Inpres 2 Nggele yakni; Demokratis. Seperti yang dikemukakan (Hourlock, 2014) hasil penelitian peneliti menemukan ada beberapa orang tua di Desa Nggele yang menerapkan pola asuh yang bercirikan pola asuh demokratis. Yakni seperti memberikan kebebasan kepada anaknya untuk melakukan apa yang diinginkan akan tetapi tetap ada pengawasan dan arahan dari orang tua kepada anak. Kemudian pola asuh berikutnya yang diterapkan oleh orang tua di Desa Nggele juga ada yang bercirikan pola asuh laissez faire, (Hardy, 2014) orang tua yang tidak pernah memberikan nafkah bagi anaknya. Bahkan untuk menanyakan kabar anaknya saja tidak pernah dengan kata lain orang tua acuh tak acuh terhadap tumbuh kembang anaknya. Pola asuh berikutnya yang diterapkan oleh orang tua di Desa Nggele ada pula yang bercirikan pola asuh Otoriter (Baumrind, 2014) yakni membuat aturan secara sepihak dan harus ditaati oleh anak, segala aturan dikendalikan oleh orang tua tanpa adanya campur tangan dari pihak anak. dan jika anak melanggar maka akan mendapatkan sangsi berupa teguran fisik seperti dicubit, dipukuli. Meskipun pola asuh ini tidak bersifat menetap pada diri orang tua di Desa Nggele, atau orang tua tidak selalu berwatak keras terhadap anak-anaknya. Dengan kata lain orang tua akan bersifat keras apabila anaknya susah untuk didik namun kemudian mereka akan kembali fleksibel jika dilihat anaknya sudah mulai menuruti arahan orang tuanya. Pola asuh berikutnya yang yang diterapkan orang tua di Desa Nggele kepada anak yakni pola asuh yang bercirikan pola asuh situasional, (Baumrind, 2014) yakni pola asuh yang diterapkan bukan hanya pada satu pola asuh saja namun semua jenis pola asuh diterapkan dengan luwes sesuai dengan kondiri yang mereka alami saat itu. Seperti kadang akan menerapkan pola asuh otoriter, kadang juga demokratis, serta kadang laissez faire. Orang tua akan bersifat fleksibel dalam menerapkan pola asuh tergantung dari kondisi yang ada. Namun dari sekian pola asuh di atas pada umumnya para orang tua di Desa Nggele hanya menerapkan dua jenis pola asuh yang objektif yaitu pola asuh demokratis dan situasional.

Dari berbagai pola asuh yang di terapkan oleh para orang tua terhadap anaknya maka muncullah beberapa model karakter atau prilaku dari anak/siswa SD Inpres 2 Nggele seperti; Anak menjadi mandiri. Anak yang berada di Desa Nggele sudah mulai bisa mencari uang sendiri untuk mencukupi sedikit kebutuhannya. Yakni dengan dia membantu orang lain dalam berjualan ataupun membantu dengan tenaga. Sifat kemandirian ini juga diperlihatkan dari prilaku anak yang sudah mulai mandiri dalam mengurus keperluannya sendiri. Yakni dengan anak sudah bisa membersihkan pakaiannya sendiri dan bahkan dia sudah mampu membantu mencucikan baju orang tua serta adiknya. Selanjutnya anak menjadi bergantung kepada orang tua. Perilaku yang muncul berikutnya dari anak yaitu anak yang menjadi berketergantungan pada orang tua atau orang-orang di sekitarnya. Karena pola pengasuhan yang diberikan oleh orang tua terlalu bersifat sepenuhnya kepada anak, yang membuat anak tidak terlatih secara intens untuk melakukan kegiatannya sendiri. Akibatnya anak menjadi manja dan tidak bisa melakukan aktivitasnya jika tidak didampingi oleh orang tuanya. Berikutnya yaitu anak menjadi bandel dan susah untuk dinasehati oleh orang tua. Berdasarkan hasil wawancara dan pengamatan peneliti, peneliti menemukan bahwa ada anak di Desa Nggele yang susah untuk diatur oleh orang tuanya bahkan ada orang tua yang kewalahan dalam menanggulangi prilaku anak. Kemudian anak menjadi penurut dan mendengarkan arahan orang tua. Sikap atau karakter yang muncul pada anak berikutnya yakni anak menurut pada perintah orang tua seperti ketika diarahkan oleh orang tua si anak mendengar dan mengikuti apa yang disampaikan orang tuanya.

Kemudian faktor yang mempengaruhi pola asuh orang tua di Desa Nggele dalam membentuk karakter anak yakni; Latar belakang pola pengasuhan yang didapatkan sebelumnya. (Manurung, 2014) Pola asuh yang para orang tua dapatkan sebelumnya sangat berpengaruh terhadap pola asuh yang akan mereka terapkan bagi anak-anaknya. Ketika para orang tua menganggap bahwa pola asuh yang mereka dapatkan sebelumnya sangat baik maka mereka tak segan menerapkan secara langsung kedalam keluarganya pula yakni kepada anak-anaknya. Status ekonomi serta pekerjaan orang tua. (Manurung, 2014) Banyak dari orang tua di Desa Nggele yang jarang berada di rumah dikarenakan oleh kesibukannya dalam bekerja atau mencari nafkah yang membuat para orang tua di sana memiliki waktu yang terbatas juga dengan anaknya. Tingkat pendidikan dari orang tua. (Manurung, 2014) Ada 
orang tua yang mencari cara agar supaya bagaimana anaknya tidak bermain sembarangan di luar rumah, yakni dengan membelikan mainan yang bisa membuat anaknya betah bermain di rumah saja. Namun ada juga yang mengambil solusi lebih kepada membiarkan anaknya untuk melakukan kemauannya sampai anaknya merasa puas dengan apa yang akan dia lakukan. Lingkungan sosial fisik tempat dimana keluarga itu tinggal. (Soekanto, 2014) Para orang tua di Desa Nggele termotivasi dari tetangganya yang rata-rata mampu menyekolahkan anak-anaknya sampai pada perguruan tinggi dan ada juga orang tua yang tertarik memberikan nasehat kepada anak-anaknya dengan menyuruh anaknya mencontoh sikap atau perilaku baik dari anak tetangganya.

\section{KESIMPULAN}

Pola Asuh Orang Tua di Desa Nggele Terhadap Pembentukan Karakter Anak (study kasus: terhadap siswa/siswi SD Inpres 2 Nggele)" yakni Demokratis, Laissez faire (acuh tak acuh, Otoriter, dan pola asuh situasional, hampir semua orang tua di Desa Nggele menerapkan pola asuh ini dalam mengasuh anak. Namun, dari sekian pola asuh di atas pada umumnya para orang tua di Desa Nggele hanya menerapkan dua jenis pola asuh yang objektif yaitu pola asuh demokratis dan situasional. Beberapa karakter yang muncul dengan adanya pola asuh yang di terapkan oleh orang tua yaitu: 1) Anak menjadi mandiri. 2) Anak menjadi bergantung kepada orang tua. 3) Anak menjadi bandel. 4) Anak menjadi penurut dan mendengarkan arahan orang tua. Faktor yang mempengaruhi pola pengasuhan orang tua di Desa Nggele terhadap pembentukan karakter anak yang bersekolah di SD Inpres 2 Nggele yaitu: 1) Latar belakang pola pengasuhan yang didapatkan sebelumnya. 2) Status ekonomi serta pekerjaan orang tua. 3) Tingkat pendidikan dari orang tua. 4) Lingkungan sosial fisik tempat dimana keluarga itu tinggal.

\section{DAFTAR PUSTAKA}

Agustiawati, I. (2014). Pengaruh Pola Asuh Orang Tua Terhadap Pretasi Belajar Siswa Pada Mata Pelajaran Akuntansi Kelas XI IPS di SMA Negeri 26 Bandung. Jurnal pendidikan, 17-20.

Akmal, N. (2017). Peran Pola Asuh Orang Tua Dalam Pembentukan Karakter Anak Usia Dini. Prosiding Seminar Nasional Tahunan Fakultas Ilmu Sosial Universitas Negeri Medan, 283.

Baumrind, I. A. (2014). Pengaruh Pola Asuh Orang Tua Terhadap Prestasi Belejar Siswa Pada Mata Pelajaran Akuntansi Kelas XI IPS di SMA Negeri 26 Bandung. 11-13.

Covey, \& Istiani, I. (2013). Pengaruh Peran Orang Tua dan Spiritual Terhadap Prilaku Kekerasan Remaja di SMP Negeri 2 Rembang Kabupaten Purbalingga. 12-14.

Dkk, Z. D. (2016). Ilmu Pendidikan Islam. Jakarta: Bumi Aksara.

Hardy, H. I. (2014). Pengaruh Pola Asuh Orang Tua Terhadap Prestasi Belejar Siswa Pada Mata Pelajaran Akuntansi Kelas XI IPS di SMA Negeri 26 Bandung. 1-13 .

Hourlock, I. A. (2014). Pengaruh Pola Asuh Orang Tua Terhadap Prestasi Belejar Siswa Pada Mata Pelajaran Akuntansi Kelas XI IPS di SMA Negeri 26 Bandung. 11-13.

Karsdi. (2018). Metode Penelitian Sosial Antara Teori dan Praktek. Yogyakarta: Pustaka Pelajar.

Manurung, I. A. (2014). Pengaruh Pola Asuh Orang Tua Terhadap Prestasi Belejar Siswa Pada Mata Pelajaran Akuntansi Kelas XI IPS di SMA Negeri 26 Bandung. 17-20.

Milles, Huberman, \& Karsadi. (2018). Metode Penelitian Sosial Antara Teori dan Praktek. Yogyakarta: Pustaka pelajar.

Rahmad, J. (2008). Islami Alternatif Ceramah-Ceramah Dikampus . 121.

Soekanto, I. A. (2014). Pengaruh Pola Asuh Orang Tua Terhadap Prestasi Belejar Siswa Pada Mata Pelajaran Akuntansi Kelas XI IPS di SMA Negeri 26 Bandung. 17-20.

Soemarjan, S., Abdullah, \& Jailan, M. S. (2014). Teori pendidikan keluarga dan tanggung jawab orang tua dalam pendidikan anak usia dini. Jurnal pendidikan, 90.

Solehuddin. (2013). Pelaksanaan Perlindungan Hukum Terhadap Pekerja Anak Yang Bekerja Dibidang Konstruksi. 5.

subianto, J., \& Koesoema. (2013). peran keluarga sekolah dan masyarakat dalam pembentukan karakter yang berkualitas. edukasia; jurnal pendidikan islam, 334. 